OPEN ACCESS

Edited by:

Dong-Ming Su,

University of North Texas Health

Science Center, United States

Reviewed by:

Nivedita Ratnam,

National Cancer Institute (NCl),

United States

Qing Ge,

Peking University, China

*Correspondence:

Andreas Lundqvist andreas.lundqvist@ki.se

Specialty section:

This article was submitted to

T Cell Biology,

a section of the journa

Frontiers in Immunology

Received: 18 March 2021

Accepted: 10 May 2021

Published: 01 June 2021

Citation:

Luu K, Schwarz H and Lundqvist A (2021) B7-H7 Is Inducible on T Cells to Regulate Their Immune Response and Serves as a Marker for Exhaustion.

Front. Immunol. 12:682627.

doi: 10.3389/fimmu.2021.682627

\section{B7-H7 Is Inducible on T Cells to Regulate Their Immune Response and Serves as a Marker for Exhaustion}

\author{
Khang Luu ${ }^{1,2,3,4,5}$, Herbert Schwarz ${ }^{1,2,3,4}$ and Andreas Lundqvist ${ }^{5 *}$ \\ ${ }^{1}$ Department of Physiology, Yong Loo Lin School of Medicine, National University of Singapore, Singapore, Singapore, \\ ${ }^{2}$ NUS Immunology Programme, Life Sciences Institute, National University of Singapore, Singapore, Singapore, ${ }^{3}$ NUSMED \\ Immunology Translational Research Programme, National University of Singapore, Singapore, Singapore, ${ }^{4}$ Integrative \\ Sciences and Engineering Programme, National University of Singapore, Singapore, Singapore, ${ }^{5}$ Department of Oncology- \\ Pathology, Karolinska Institutet, Stockholm, Sweden
}

The discovery of immune checkpoints highlights the complexity of $\mathrm{T}$ cell signalling during an immune response. Upon activation, $T$ cells express several molecules to regulate their function and to prevent overactivation. B7 homolog $7(\mathrm{~B} 7-\mathrm{H} 7)$ is expressed in tumours and associated with a worse prognosis. However, conflicting data regarding its function suggest that it can be both stimulatory and inhibitory. In this study we report that $\mathrm{B} 7-\mathrm{H} 7$ is also expressed on T cells upon cross-linking of CD3 and CD28 and that additional stimulation via CD137 further enhances the expression of $\mathrm{B} 7-\mathrm{H} 7 . \mathrm{B} 7-\mathrm{H} 7$ is preferentially expressed on exhausted Th1 and Tc1 cells with an impaired secretion of TNF- $\alpha$ and IFN- $\gamma$. Blockade of $\mathrm{B} 7-\mathrm{H} 7$ with its natural receptor, recombinant $\mathrm{CD} 28 \mathrm{H}$, enhances $\mathrm{T}$ cell proliferation and activation. Thus, B7-H7 represents another target for immunotherapy and a biomarker to select for active effector $\mathrm{T}$ cells with relevance for adoptive cell transfer therapy.

Keywords: immunology, immune checkpoint, T lymphocyte, exhaustion, immunotherapy

\section{INTRODUCTION}

B7-H7 is originally discovered as HHLA2 ( Human-endogenous-retroviruses- $\underline{\mathrm{H}}$ Long-terminalrepeat Associating protein 2), in the search for new members of the Immunoglobulin (Ig) superfamily (1). For some time, B7-H7 was confusingly addressed as B7-H5, which is now reserved for VISTA (V-domain Ig suppressor of $\mathrm{T}$ cell activation), another member of the Ig superfamily. Beside in humans, B7-H7 is also found in several other species including fish, frog, panda and monkey. Curiously, it is not expressed in laboratory mice and rats (2).

In normal tissue, B7-H7 is expressed mainly in the gastrointestinal track, and the placenta, where immunoregulation is essential (3). On leukocytes, its expression is reported mainly on antigenpresenting cells (monocytes, B lymphocytes, and dendritic cells) (4). B7-H7 has also been reported to be widely expressed on a variety of human cancers (such as breast, lung and melanoma), and is associated with worse disease outcome $(3,5-8)$. 
As the name suggests, B7-H7 shares varying degree of amino acid identity and similarity with other human B7 molecules, such as B7.1/CD80, B7.2/CD86, B7-H1/PD-L1, and B7-H2/PD-L2 (2). For $\mathrm{T}$ cells to be optimally activated, they need to receive $\mathrm{T}$-cell receptor stimulation (signal 1 ), costimulatory signal via costimulatory receptors like CD28 (signal 2) and cytokine stimulation (signal 3) (9). B7 family members CD80 and CD86 directly costimulate T cells via CD28 (9), while members like PD-L1 and PD-L2 inhibit T cell activation via PD-1 (10). Given the essential roles of $\mathrm{B} 7$ family molecules, it is reasonable to assume that $\mathrm{B} 7-\mathrm{H} 7$ is involved in the regulation of immune response. At the time $\mathrm{B} 7-\mathrm{H} 7$ function was first assessed, two independent groups showed conflicting results that B7-H7 can be both stimulatory and inhibitory. Zhao et al. reported that B7$\mathrm{H} 7$ inhibit T cells proliferation and cytokine secretion (2), while Zhu et al. demonstrated that B7-H7 co-stimulates T cells via its receptor $\mathrm{CD} 28 \mathrm{H}$ (4). Following these initial report, more recent studies have also reported both inhibitory and stimulatory functions of B7-H7 (11-13).

Since different groups presented conflicting data on the function of B7-H7, a concept of dual functionality was proposed, as is the case of CD80/CD86 and CD28/CTLA-4. Along these lines, Bhatt et al. recently proposed that $\mathrm{CD} 28 \mathrm{H}$ acts as an immunostimulatory receptor whereas KIR3DL3 instead inhibit immune responses upon ligation of B7-H7 (14).

The definition of $\mathrm{T}$ cell exhaustion remains a debatable and rapidly developing field in immunology, and there is no single consensus to define $\mathrm{T}$ cell exhaustion. During chronic antigen presentation, $\mathrm{T}$ cells assume a hypofunctional state with reduced effector functions, cytokine secretion, proliferation, and increased expression of immunoinhibitory checkpoints. This phenomenon is not always viewed as detrimental because it is necessary to prevent immunopathology, limit damage to normal tissue, and allow the T cell to persist and control the disease (15).

In this study, we report that $\mathrm{T}$ cells can also express B7-H7 and that the expression is only induced upon activation. $\mathrm{T}$ cells expressing $\mathrm{B} 7-\mathrm{H} 7$ also shows an exhausted type $1 \mathrm{~T}$ cell phenotype, and blockade of $\mathrm{B} 7-\mathrm{H} 7$ with recombinant human $\mathrm{CD} 28 \mathrm{H}$ significantly increases $\mathrm{T}$ cell activation and proliferation.

\section{MATERIALS AND METHODS}

\section{Gene Expression Data Analysis}

For HHLA2/B7-H7 mRNA expression analysis in normal immune subsets, we employed In Silico Transcriptomic (IST) Online by Medisapiens (https://ist.medisapiens.com/), which comprises of a large database from normal and pathological human tissues and cells. We also used Human Protein Atlas project (https://www.proteinatlas.org/) (16). Both databases are updated as of $17^{\text {th }}$ Mar 2021.

Published databases were extracted and visualized via the R2: Genomics Analysis and Visualization Platform (http://r2.amc.nl). For Figure 1A, T-cell peripheral lymphoma patient overall survival probability analysis, out of 193 patients, only 162 patients with survival data were included, the follow up period was selected to be 60 months (GEO: gse58445) (17).
For mRNA expression visualization in R2, the following databases were used: B-ALL (GEO: gse7440, n=98) (18), DLBCL (GEO: gse87371, n=223) (19), AML (GEO: gse14468, $\mathrm{n}=525$ ) (20), T-ALL (GEO: gse10609, $\mathrm{n}=92)$ (21), T-cell peripheral lymphoma (GEO: gse58445, n=193) (17).

\section{Cell Lines}

HDLM-2 (kindly provided by Dr. G Rassidakis, Karolinska Institutet) was cultured at $37^{\circ} \mathrm{C}$ in $5 \% \mathrm{CO}_{2}$, in RPMI 1640 medium (Gibco, Thermo Fisher Scientific), supplemented with $20 \%$ heat inactivated fetal bovine serum (FBS) (Gibco), and 1\% Penicillin and Streptomycin (Gibco). Jurkat (ATCC) and MAC-1 cells (kindly provided by Dr. G Rassidakis, Karolinska Institutet) were cultured at $37^{\circ} \mathrm{C}$ with $5 \% \mathrm{CO}_{2}$, in RPMI 1640 medium (Gibco), supplemented with 10\% heat inactivated FBS (Gibco), and $1 \%$ Penicillin and Streptomycin (Gibco).

\section{Primary Human Cell Isolation}

Peripheral blood mononuclear cells (PBMC) were isolated from buffy coat by Ficoll gradient centrifugation (GE healthcare) and washed three times in PBS. T cells were negatively selected with magnetic-assisted cell sorting (MACS) from PBMC with the use of $\mathrm{CD}^{+} \mathrm{T}$ cell isolation kit or Pan $\mathrm{T}$ cell isolation kit (Miltenyi Biotec). Primary human T cells were cultured in RPMI 1640 medium (Gibco), supplemented with $10 \%$ heat inactivated FBS (Gibco), and 1\% Penicillin and Streptomycin (Gibco). Monocytes were positively selected with MACS by CD14 Microbeads (Miltenyi Biotec) and were cultured in RPMI 1640 medium (Gibco), supplemented with $10 \%$ heat inactivated FBS (Gibco), and 1\% Penicillin and Streptomycin mixture (Gibco).

\section{Activation of Human Primary Cells}

For $\mathrm{T}$ cell activation, $\mathrm{T}$ cells were cultured at a concentration of $10^{6}$ cells $/ \mathrm{ml}$. TransAct ${ }^{\mathrm{TM}}$ (Miltenyi Biotec), a nanomatrix coated with CD3 agonist and CD28 agonist, was used at the manufacturer's recommended dilution of 1:100, unless otherwise stated. When used, Torin-1 (Selleck Chemicals) was added to cultures at $1 \mathrm{nM}$. To study the dynamic of B7-H7 expression, $\mathrm{T}$ cells were treated with TransAct ${ }^{\mathrm{TM}}$ for 72 hours, washed and reseeded in fresh medium containing $100 \mathrm{IU} / \mathrm{ml}$ of IL-2 (Novartis) or fresh medium containing the recommended dose of TransAct ${ }^{\text {TM }}$ for another 72 hours. For blocking of B7-H7, recombinant human $\mathrm{CD} 28 \mathrm{H}$ ( $\mathrm{R} \& \mathrm{D}$ systems) was added at $5 \mu \mathrm{g} /$ $\mathrm{ml}$ together with suboptimal dose of TransAct ${ }^{\mathrm{TM}}$ (1:1000), and the cells were cultured for 72 to 96 hours. To immobilize CD137L or anti-CD3, recombinant human CD137L (R\&D systems) or anti-CD3 (clone OKT3, Biolegend) was coated at 1 $\mu \mathrm{g} / \mathrm{ml}$ on a Falcon ${ }^{\circledR}$ 96-well Clear Flat Bottom (Corning Life Sciences) overnight at $4^{\circ} \mathrm{C}$, then washed twice with PBS, before $\mathrm{T}$ cells were seeded. $100 \mathrm{ng} / \mathrm{mL}$ Phorbol 12-myristate 13-acetate (PMA) and $1 \mu \mathrm{g} / \mathrm{mL}$ ionomycin was added to purified $\mathrm{T}$ cells for 24 hours.

\section{Mixed Lymphocyte Reaction}

Isolated monocytes were seeded at $10^{6}$ cells $/ \mathrm{ml}$, supplemented with $100 \mathrm{ng} / \mathrm{ml} \mathrm{IL-4}$ at and $80 \mathrm{ng} / \mathrm{ml} \mathrm{GM-CSF}$ (Peprotech) for five days, to be differentiated to monocyte-derived dendritic cells. 


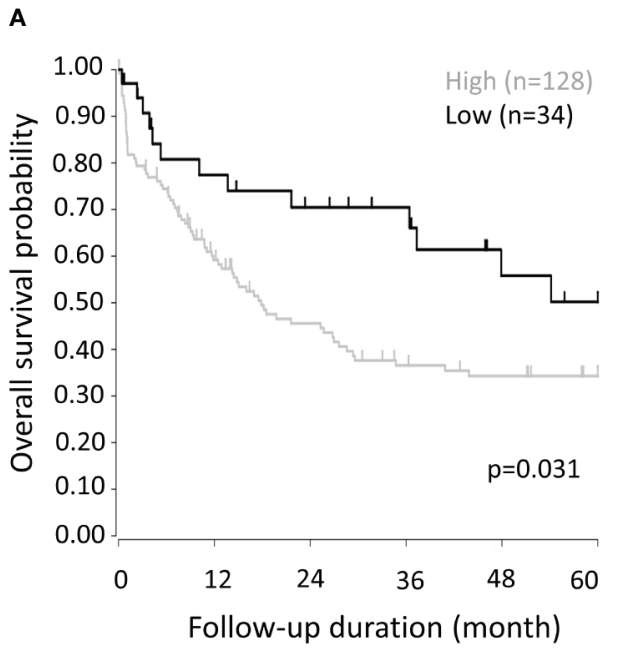

C

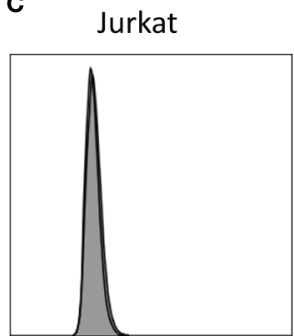

HDLM-2

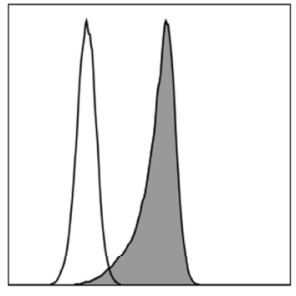

B7-H7
B

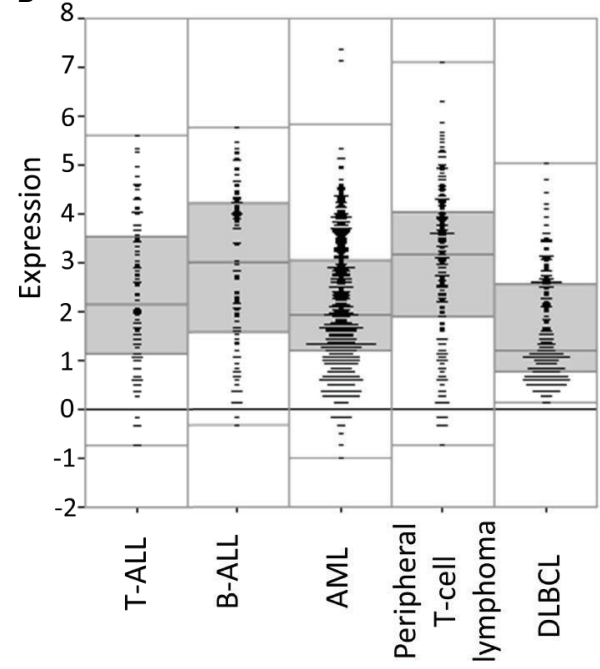

D

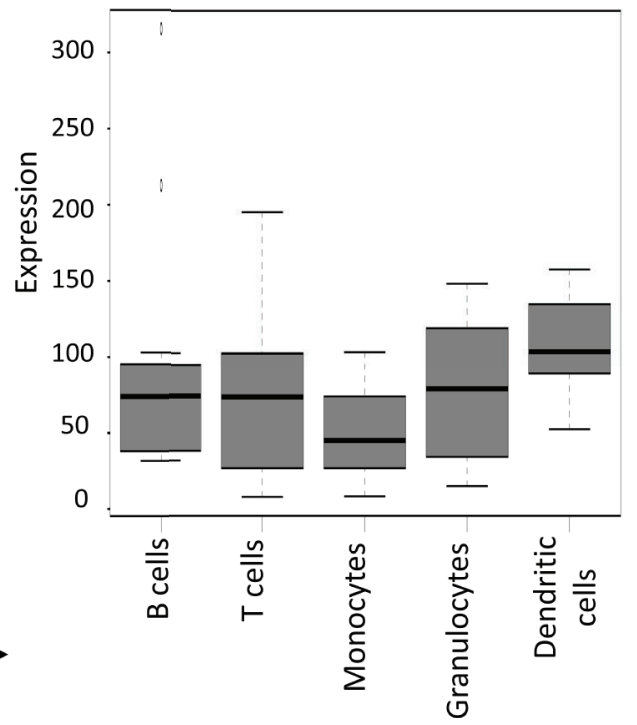

FIGURE 1 | Expression of HHLA2/B7-H7 in T cells. (A) Overall sunvival outcome of T-cell peripheral lymphoma patients with high (expression value $\geq 3$ ) versus low (expression value<3) expression level of $\mathrm{B} 7-\mathrm{H} 7$. Of the 193 patients, only 162 provided survival data, for which overall survival probability over five years is calculated, using the log-rank test. (B) B7-H7 RNA expression analysis according to R2 data visualization platform for DLBCL (GEO: gse87371), B-ALL (GEO: gse7440), AML (GEO: gse14468) T-ALL (GEO: gse10609) and T-cell peripheral lymphoma patients (GEO: gse58445). (C) B7-H7 expression on different cell lines with T cells origin: Jurkat, HDLM-2 and MAC-1. Cells were gated for live and single cells. (D) B7-H7 RNA expression analysis on normal immune cell subsets, according to IST Online MediSapiens.

For maturation of DC, LPS (SigmaAldrich) was added on day five at $5 \mu \mathrm{g} / \mathrm{ml}$. On day six, mature DC were harvested, and $4 \mathrm{x}$ $10^{4}$ mature DC were co-cultured with $2 \times 10^{5}$ allogenic T cells for six days.

\section{Flow Cytometry}

For surface marker staining, cells were incubated with dead cell marker, followed by $\mathrm{Fc}$ receptor blocking reagents, then with a mixture containing the relevant fluorophore-conjugated antibodies (Supplementary Table 1), and finally using a fixing reagent, $\mathrm{BD}$ Cytofix ${ }^{\mathrm{TM}}$ (BD Bioscience). For intracellular staining, eBioscience ${ }^{\mathrm{TM}}$ Foxp3/Transcription Factor Staining Buffer Set (Thermo Fisher Scientific) was used according to the manufacturer's instructions. All flow cytometry data was analyzed by Treestar FlowJo program.

\section{Statistical Analysis}

Statistical analyses were performed using Prism Graphpad software. Survival analysis was performed using the R2 platform. Student's t test was used to compare the difference 
between two groups, and one-way ANOVA with multiple comparison tests were used to compare multiple groups. Overall survival probability was calculated using the logrank test.

\section{RESULTS}

\section{B7-H7 Is Expressed on Human T-Cell Haematological Cancers and Cell Lines of T- Cell Origin}

Consistent with previous reports that $\mathrm{B} 7-\mathrm{H} 7$ expression is associated with poor prognosis, we observed that high B7-H7 expression was a prognosis marker for peripheral $\mathrm{T}$-cell lymphoma (Figure 1A). Comparing B7-H7 expression level of peripheral T-cell lymphoma patients with that of other haematological cancers, similar levels of expression was observed for B-cell acute lymphoblastic leukaemia (B-ALL) and T-cell acute lymphoblastic leukaemia (T-ALL) whereas Diffuse Large B Cell Lymphoma (DLBCL) and acute myeloid leukaemia (AML) showed lower expression of B7-H7. (Figure 1B). To validate these results, B7-H7 protein expression was assessed on the thymic $\mathrm{T}$ cell line Jurkat, HDLM-2 (A Hodgkin lymphoma cell line with $\mathrm{T}$ cell origin (22)), and MAC-1 (a cutaneous T-cell non-Hodgkin lymphoma cell line). While no expression of B7-H7 was detected on Jurkat cells, both HDLM-2 and MAC-1 expressed high levels of B7-H7 (Figure 1C).

While antigen-presenting cells and myeloid cells were reported to be the major cell types that expressed B7-H7, mRNA expression data from IST Medisapiens demonstrated that B7-H7 was expressed on most immune cells at the RNA level, including T cells (Figure 1D). Other public databases also verified that while $\mathrm{T}$ cell might not have the highest level of B7$\mathrm{H} 7$ expression, B7-H7 transcript was consistently detected in $\mathrm{T}$ cells (Figure S1). Taken together, these findings suggest that primary T cells and T-cell related tumours could express B7-H7 at the protein level.

\section{B7-H7 Expression Is Induced on T Cells Upon Activation via CD3 and CD28}

Consistent with previous reports, the expression of $\mathrm{B} 7-\mathrm{H} 7$ was absent on resting T cells (Figure 3A). Cross-linking of CD3 alone or mitogenic stimulation by Phorbol 12-myristate 13-acetate (PMA) and Ionomycin did not increase B7-H7 expression (Figure 2A). However, upon activation of purified $\mathrm{T}$ cells through cross-linking of $\mathrm{CD} 3$ and $\mathrm{CD} 28$, both $\mathrm{CD}^{+}$and $\mathrm{CD}^{+} \mathrm{T}$ cells expressed $\mathrm{B} 7-\mathrm{H} 7$, demonstrating that other signals including the cross-linking of CD28 was needed for the induction of B7-H7 expression. Although significant, the expression of $\mathrm{B} 7-\mathrm{H} 7$ was on average $4 \%$ higher in $\mathrm{CD}^{+} \mathrm{T}$ cells compared with $\mathrm{CD}^{+} \mathrm{T}$ cells (Figure 2B). Analysis of markers of $\mathrm{T}$ cell differentiation revealed that the majority of the $\mathrm{B} 7-\mathrm{H}^{+}{ }^{+} \mathrm{T}$ cells are $\mathrm{CD} 57^{-}$and $\mathrm{OX} 40^{+}$, describing a state of activation but not terminal differentiation (Figure 2C).

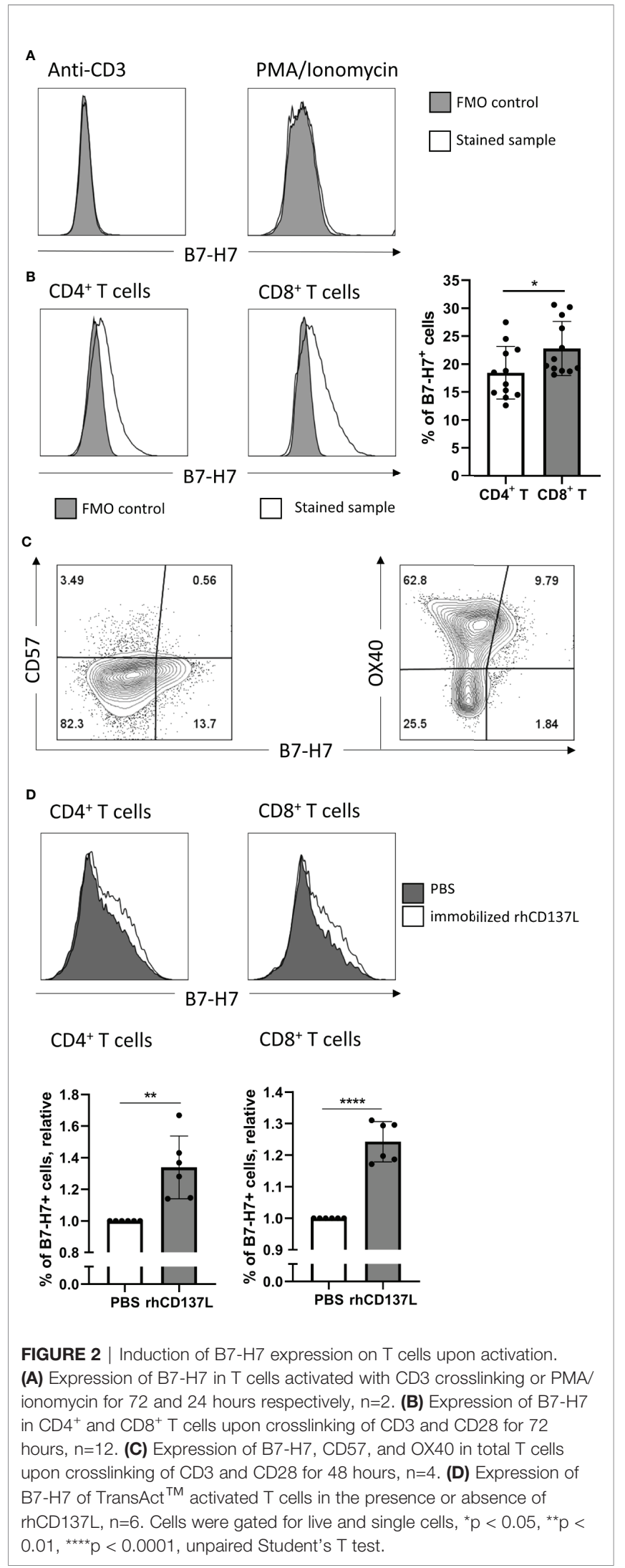


To test if additional costimulatory signals such as CD137 stimulation would further increase the expression of B7-H7, $\mathrm{CD} 3 / \mathrm{CD} 28$ activated $\mathrm{T}$ cells were cultured in the presence or absence of recombinant human CD137 ligand (rhCD137L). Indeed, the expression of $\mathrm{B} 7-\mathrm{H} 7$ was significantly higher in both $\mathrm{CD}^{+}$and $\mathrm{CD}^{+} \mathrm{T}$ cells in the presence of rhCD137L (Figure 2D). To test whether other stimuli can induce B7-H7 on $\mathrm{T}$ cells, we performed a mixed lymphocyte reaction and observed B7-H7 on activated CD25 ${ }^{+} \mathrm{T}$ cells (Figure S2).

\section{The Expression of B7-H7 Is Dynamic and Dependent on the Stimulation Strength and mTOR Activity}

Upon further investigation into the expression kinetics, B7-H7 was detected at 24 hours after stimulation, and the expression plateaued after 72 hours, on both $\mathrm{CD} 4^{+}$and $\mathrm{CD} 8^{+} \mathrm{T}$ cells (Figure $3 \mathbf{A}$ ). To test whether the strength of $\mathrm{CD} 3 / \mathrm{CD} 28$ cross-linking influences the expression of $\mathrm{B} 7-\mathrm{H} 7$, increasing concentrations of $\mathrm{CD} 3 / \mathrm{CD} 28$ agonists (TransAct ${ }^{\mathrm{TM}}$ ) were added to $\mathrm{T}$ cells. At lower concentrations, the expression of $\mathrm{B} 7-\mathrm{H} 7$ was significantly reduced on both $\mathrm{CD}^{+}$and $\mathrm{CD} 8^{+} \mathrm{T}$ cells (Figure 3B). To further understand if the expression of $\mathrm{B} 7-\mathrm{H} 7$ fluctuates during activation, T cells were first activated with agonists for CD3 and CD28 (TransAct ${ }^{\mathrm{TM}}$ ) for 72 hours and thereafter washed and rested in media containing IL-2 for maintenance, or immediately restimulated with CD3 and CD28 agonists (TransAct ${ }^{\mathrm{TM}}$ ) for another 72 hours. In restimulated $\mathrm{CD} 4^{+}$ and $\mathrm{CD}^{+} \mathrm{T}$ cells, the expression of $\mathrm{B} 7-\mathrm{H} 7$ was maintained, whereas it was significantly reduced in rested $\mathrm{CD}^{+}$and $\mathrm{CD}^{+} \mathrm{T}$ cells (Figure 3C). Since mTOR activity can affect the expression of immune checkpoints, including PD-1 and PD-L1 (23-25), mTOR was inhibited during the activation of $\mathrm{T}$ cells to test if its activity is linked to the expression of B7-H7. Indeed, in the presence of the mTOR inhibitor Torin-1, the expression of B7-H7 is significantly reduced both $\mathrm{CD}^{+}$and $\mathrm{CD}^{+} \mathrm{T}$ cells, demonstrating that the expression of $\mathrm{B} 7-\mathrm{H} 7$ is dependent on the mTOR pathway (Figure 3D).

\section{T Cells Use B7-H7 to Regulate Their Immune Response}

Given the expression of B7-H7 on activated T cells, we hypothesized that it might act as a negative feedback mechanism to regulate $\mathrm{T}$ cell activation. Thus, $\mathrm{B} 7-\mathrm{H} 7$ was blocked with soluble recombinant human $\mathrm{CD} 28 \mathrm{H}$ (rhCD28H) as it was identified as one of B7-H7's receptors. Indeed, in the presence of rhCD28H, proliferation of $\mathrm{T}$ cells was significantly increased (Figure 4A). Furthermore, the frequency of nonactivated CD25 ${ }^{-} \mathrm{PD}-1^{-} \mathrm{T}$ cells was significantly lower in the presence of rhCD28H (Figure 4B). We also observed a consistent, albeit statistically insignificant, upregulation of IFN- $\gamma$ secretion upon the addition of $\mathrm{rhCD} 28 \mathrm{H}$ (data not shown). Analysis of B7-H7 expression in activated $\mathrm{T}$ cells revealed that $\mathrm{B} 7-\mathrm{H}^{-} \mathrm{T}$ cells produced higher levels of inflammatory cytokines such as TNF- $\alpha$ and IFN- $\gamma$ (Figures 4C, D). These results support that B7-H7 on $\mathrm{T}$ cells functions as an inhibitory ligand to control $\mathrm{T}$ cell activation, and $\mathrm{T}$ cells that express $\mathrm{B} 7-\mathrm{H} 7$ do not produce the inflammatory cytokines TNF- $\alpha$ and IFN- $\gamma$.
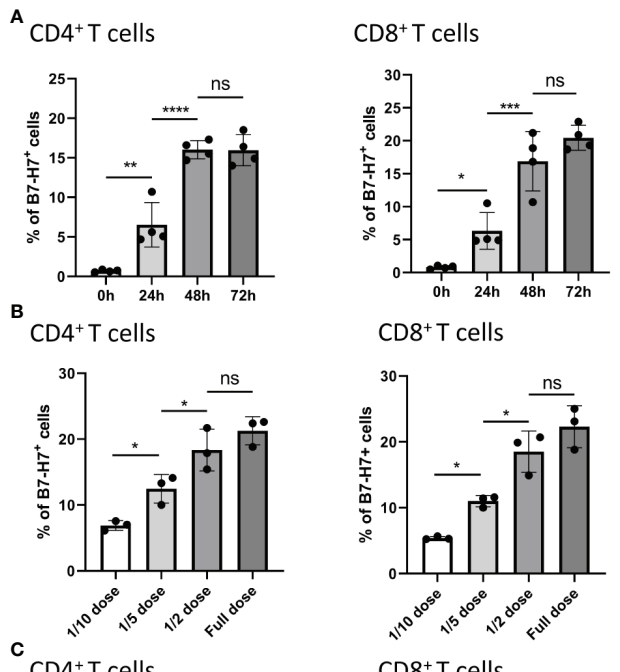

$\mathrm{CD}^{+} \mathrm{T}$ cells
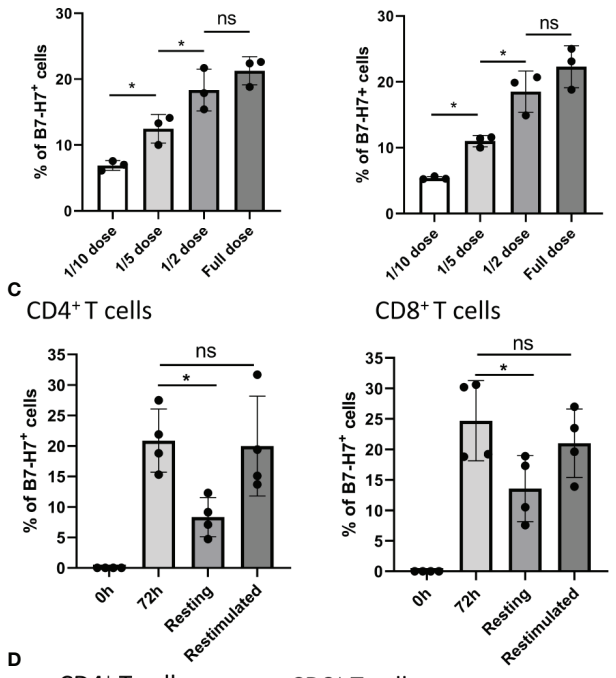

$\mathrm{CD}^{+} \mathrm{T}$ cells
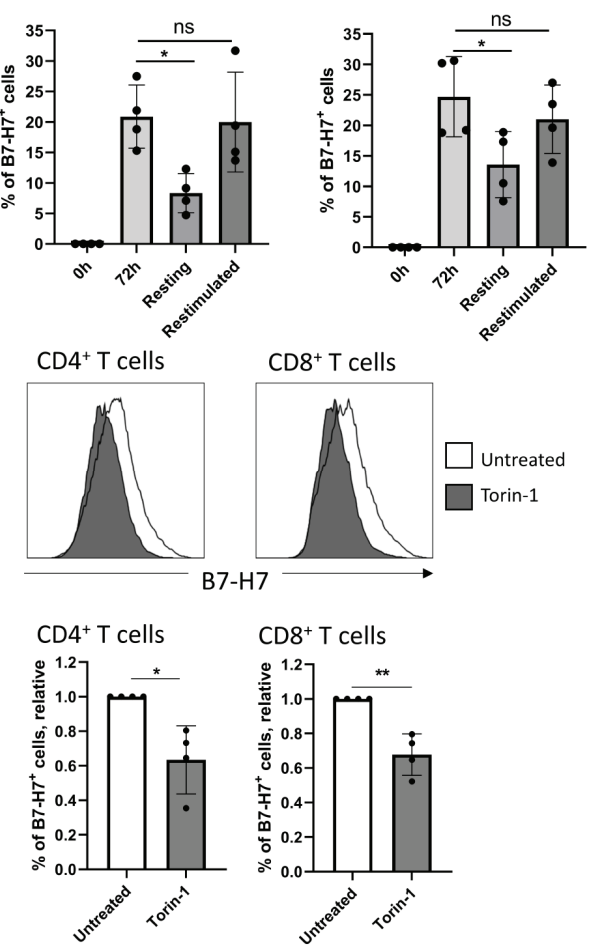

FIGURE 3 | Expression of B7-H7 is dynamic and dependent on mTOR activity. (A) B7- $\mathrm{H} 7$ expression on $\mathrm{CD} 4+$ and $\mathrm{CD} 8+\mathrm{T}$ cells at 24,48 , or 72 hours, $n=4$. (B) Expression of $B 7-H 7$ at different dilutions of TransAct ${ }^{T M}$. Full dose of TransAct ${ }^{\mathrm{TM}}$ is 1:100 dilution, $\mathrm{n}=3$. (C) $\mathrm{B} 7-\mathrm{H} 7$ expression in activated, resting and re-stimulated $T$ cells. Purified $T$ cells were activated with the recommended dose of TransAct ${ }^{\mathrm{TM}}$ (1:100) for 72 hours, washed and reseeded in fresh medium containing $100 \mathrm{IU} / \mathrm{ml}$ of IL-2 ('resting') or fresh medium containing the standard dose of TransAct $^{\mathrm{TM}}$ for another 72 hours ('restimulated'), $\mathrm{n}=4$. (D) Relative expression of B7-H7 in TransAct ${ }^{\mathrm{TM}}$ (1:100) activated $\mathrm{T}$ cells in the presence or absence of the mTOR inhibitor Torin-1 $(1 \mathrm{nM})$ or untreated control, $\mathrm{n}=4$. Cells were gated for live and single cells. ns, not significant, ${ }^{*} p<0.05,{ }^{* \star} p<0.01,{ }^{* \star *} p<0.001{ }^{* \star * *} p<0.0001$. For comparison between 2 variables, unpaired Student's T test was used. To compare multiple variables, one-way ANOVA was used, followed by multiple comparison tests. 


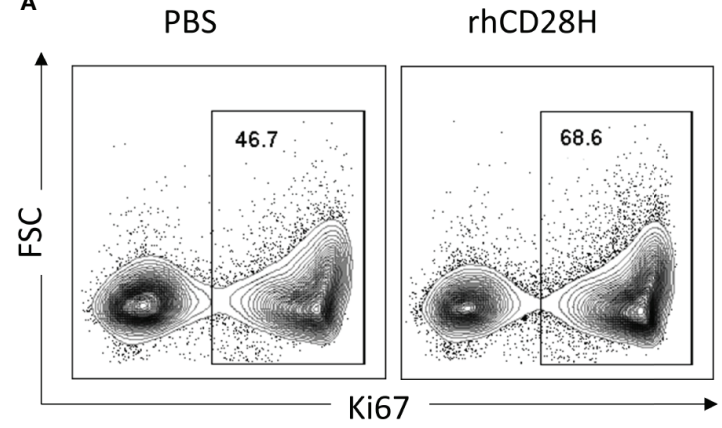

PBS

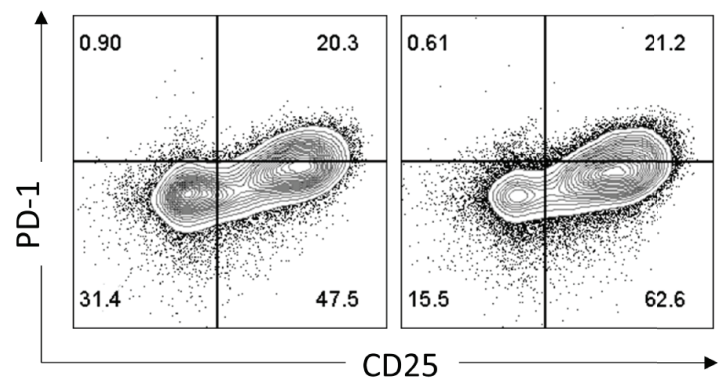

C Donor 1

Donor 2

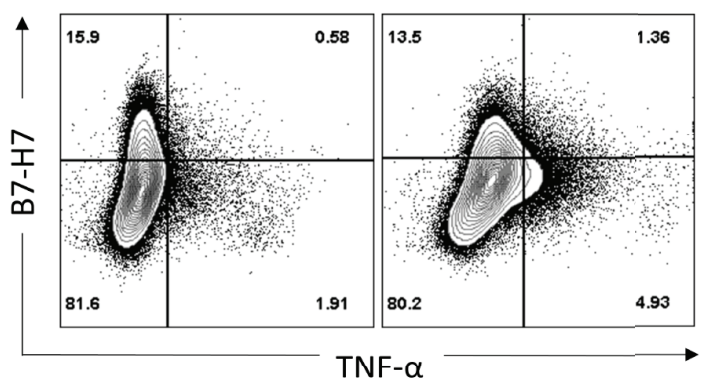

D

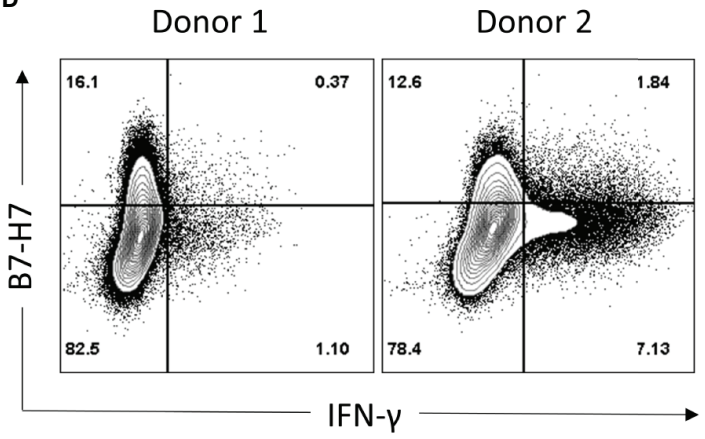

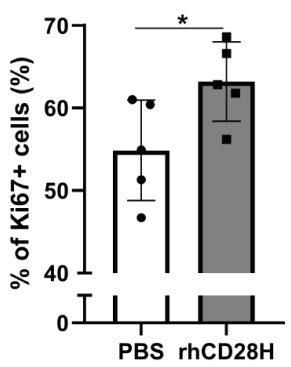
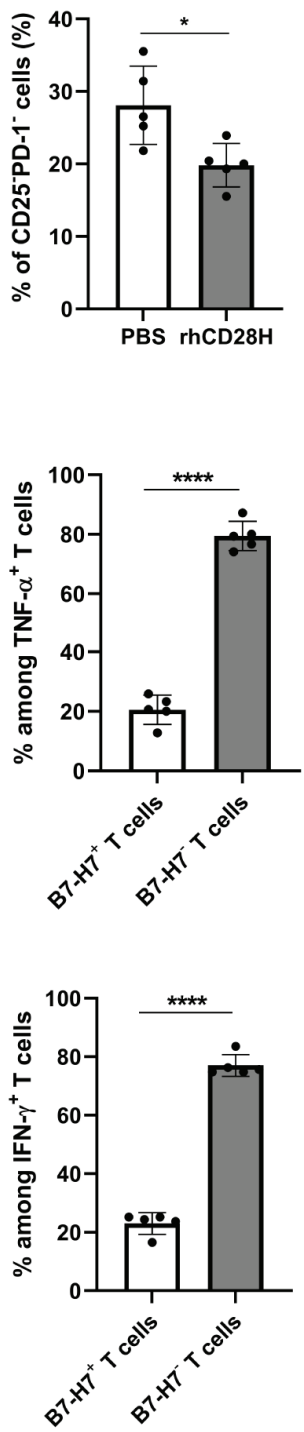

FIGURE 4 | Blocking B7-H7 enhances T cell proliferation. Purified T cells were activated with suboptimal 1/10 TransAct ${ }^{\text {TM }}$ dose (1:1000) for three to four days in the presence of PBS or $5 \mu \mathrm{g} / \mathrm{ml}$ of recombinant human CD28H (rhCD28H) and stained for (A) ki67 or (B) CD25 and PD1, n=5. Purified T cells were activated with recommended dose of TransAct ${ }^{\mathrm{TM}}$ (1:100) for three days and stained for B7-H7, (C) TNF- $\alpha$ and (D) IFN- $\gamma, \mathrm{n}=5$. Dot plots from two representative donors are shown. Cells were gated for live and single cells. ${ }^{\star} \mathrm{p}<0.05$, ${ }^{\star \star \star \star} \mathrm{p}<0.0001$, unpaired Student's $\mathrm{T}$ test. 


\section{B7-H7 as a Marker for Exhausted Th1 and Tc1 Subsets}

Since B7-H7 ${ }^{+} \mathrm{T}$ cells secrete minimal amounts of TNF- $\alpha$ and IFN- $\gamma$, we hypothesized that they were either exhausted or that they did not belong to the Th1 or Tcl subpopulations. The phenotypic markers CXCR3 and CCR6 were previously described to distinguish cytotoxic and helper $\mathrm{T}$ cell subpopulations (26-28). Thus, to investigate for different subsets of $\mathrm{T}$ cells in relation to $\mathrm{B} 7-\mathrm{H} 7$ expression, activated $\mathrm{T}$ cells were analyzed for the expression of CXCR3 (a marker of type-1 phenotype) and CCR6 (a marker of type-17 phenotype). When all $\mathrm{T}$ cells were assessed, type- 1 cells were assessed regardless of whether the T cell expressed CD4 or CD8. Hence, the term Th1/Tc1 refers to both subpopulations. Whenever the analysis could tell that those T cells express CD4 or CD8, the term Th1 or Tc1 was used respectively.

Regardless of B7-H7 expression, the majority of $\mathrm{T}$ cells committed to the Th1/Tc1 subset upon crosslinking of CD3 and CD28 as evidenced by the high expression of CXCR3 (Figure 5A). Furthermore, while the expression profile on B7$\mathrm{H}^{-} \mathrm{T}$ cells closely mirrored that of total $\mathrm{T}$ cell population, B7$\mathrm{H}^{+} \mathrm{T}$ cells were enriched in CXCR3 expression, suggesting a stronger type 1 phenotype in $\mathrm{B} 7-\mathrm{H}^{+} \mathrm{T}$ cells (Figure 5A).

Upon further subpopulation analysis, this enrichment effect of B7-H7 status for type $1 \mathrm{~T}$ cell phenotype was observed in both $\mathrm{CD}^{+}$and $\mathrm{CD}^{-} \mathrm{T}$ cells (Figure S3). Notably, the CXCR3 enrichment effect of $\mathrm{B} 7-\mathrm{H} 7$ in $\mathrm{CD}^{-} \mathrm{B} 7-\mathrm{H} 7^{+} \mathrm{T}$ cells was stronger than in $\mathrm{CD}^{+} \mathrm{B} 7-\mathrm{H}^{+} \mathrm{T}$ cells (Figure S3B). Thus, isolated $\mathrm{CD}^{+} \mathrm{T}$ cells were used to determine if the enrichment effect still could be clearly observed, as seen on CD4 ${ }^{-} \mathrm{T}$ cells when whole $\mathrm{T}$ cell population was used. $\mathrm{CD}^{+} \mathrm{T}$ cells were purified, activated, and analyzed for the expression of B7-H7, CXCR3, and CCR6. Consistent with the subpopulation analysis with CD4 cells and similar to the observation for the total $\mathrm{T}$ cell population, the expression profile of $\mathrm{CD}^{+} \mathrm{B} 7-\mathrm{H}^{-} \mathrm{T}$ cells was similar to that of all $\mathrm{CD}^{+} \mathrm{T}$ cells, while $\mathrm{B} 7-\mathrm{H} 7^{+} \mathrm{CD} 8^{+} \mathrm{T}$ cells expressed significantly higher levels of CXCR3 compared with $\mathrm{CD} 8^{+} \mathrm{B} 7$ $\mathrm{H}^{-} \mathrm{T}$ cells (Figure $\mathbf{5 B}$ ).

Since the majority of $\mathrm{B} 7-\mathrm{H}^{+} \mathrm{T}$ cells expressed markers associated with Th1 or Tc1 subsets and they had an impaired production of IFN- $\gamma$ and TNF- $\alpha$, T cells were analyzed for the expression of markers associated with exhaustion. Compared with total $\mathrm{T}$ cells, B7-H7 ${ }^{+} \mathrm{T}$ cells were enriched for PD-1 and LAG-3 (Figure 6A). Similarly, when purified $\mathrm{CD}^{+} \mathrm{T}$ cells were activated, $\mathrm{CD} 8^{+} \mathrm{B} 7-\mathrm{H} 7^{+} \mathrm{T}$ cells also showed significantly higher frequency of PD- $1^{+}$LAG- $3^{+}$cells compared with $\mathrm{CD}^{+}$B7-H7 ${ }^{-}$T cells or total purified $\mathrm{CD}^{+} \mathrm{T}$ cells (Figure 6B). Taken together, these results show that B7-H7 can serve as a marker for exhausted Th1 or Tc1 subsets that secrete minimal TNF- $\alpha$ or IFN- $\gamma$.

\section{DISCUSSION}

As the case frequently is, tumours escape immunosurveillance not by devising a new pathway, but rather by hijacking an existent immunoregulatory pathway. In this study, we report that human

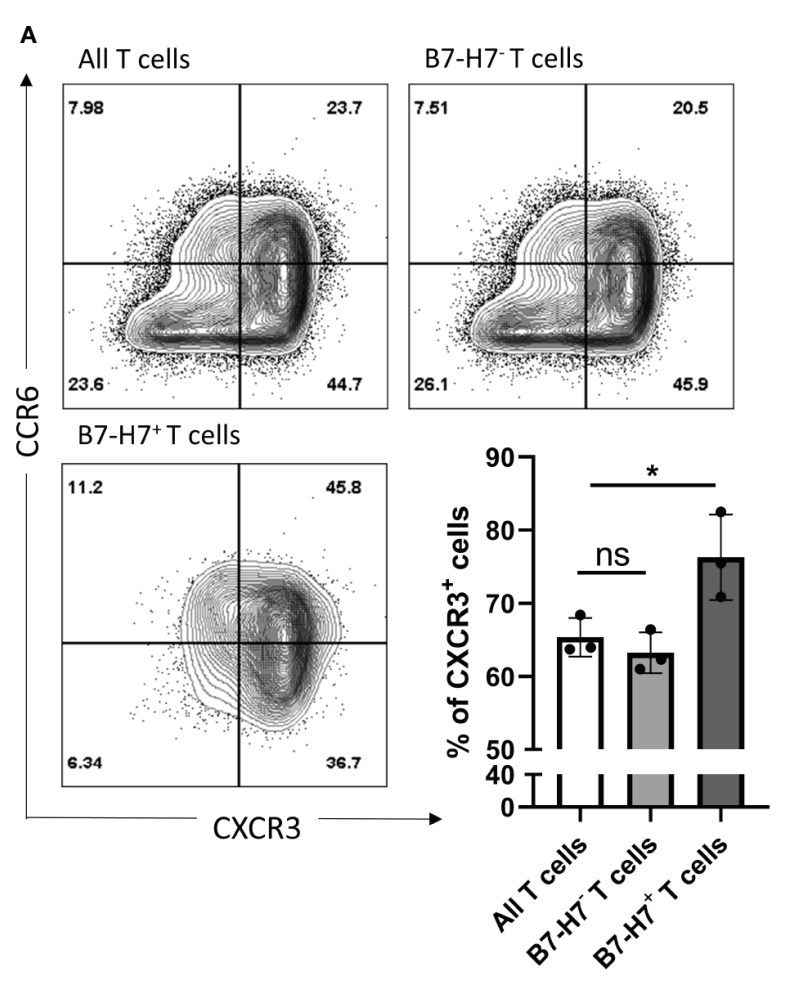

B

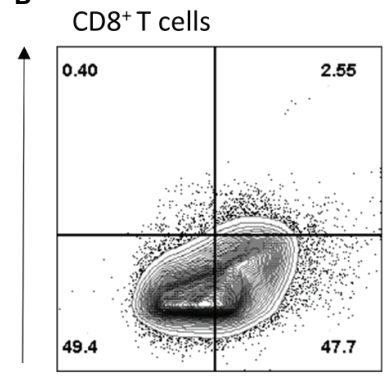

B7-H7- CD8 + T cells

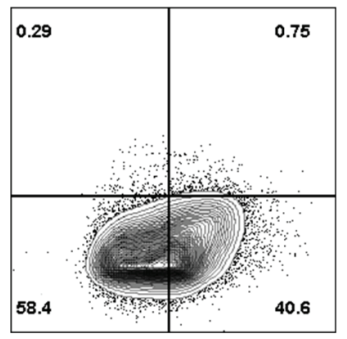

守
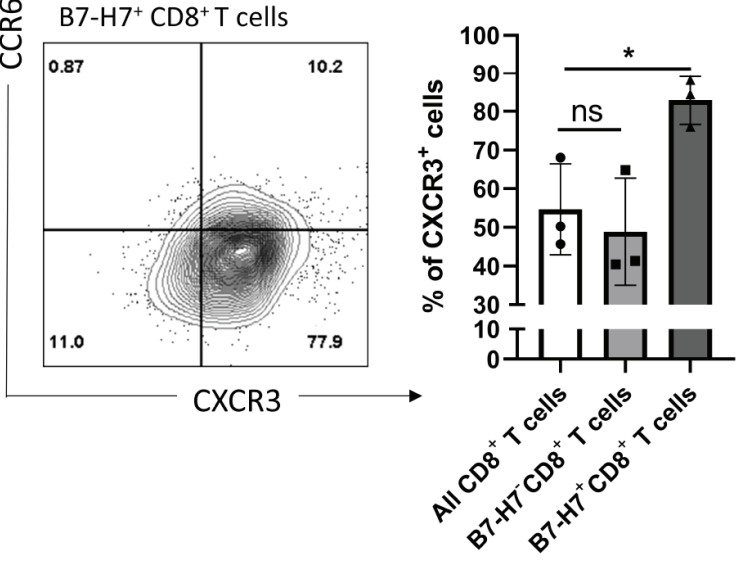

FIGURE 5 | CXCR3 and CCR6 expression profiles of total and CD8 purified T cells. Purified T cells (A) or purified CD8 ${ }^{+} T$ cells $(\mathbf{B})$ were activated with recommended dose of TransAct ${ }^{\mathrm{TM}}$ (1:100) for three days, and assessed for $\mathrm{B} 7-\mathrm{H} 7, \mathrm{CXCR} 3$ and CCR6, $n=3$. Cells were gated for live and single cells. ns, not significant, ${ }^{\star} p<0.05$, one-way ANOVA was used, followed by multiple comparison tests. 


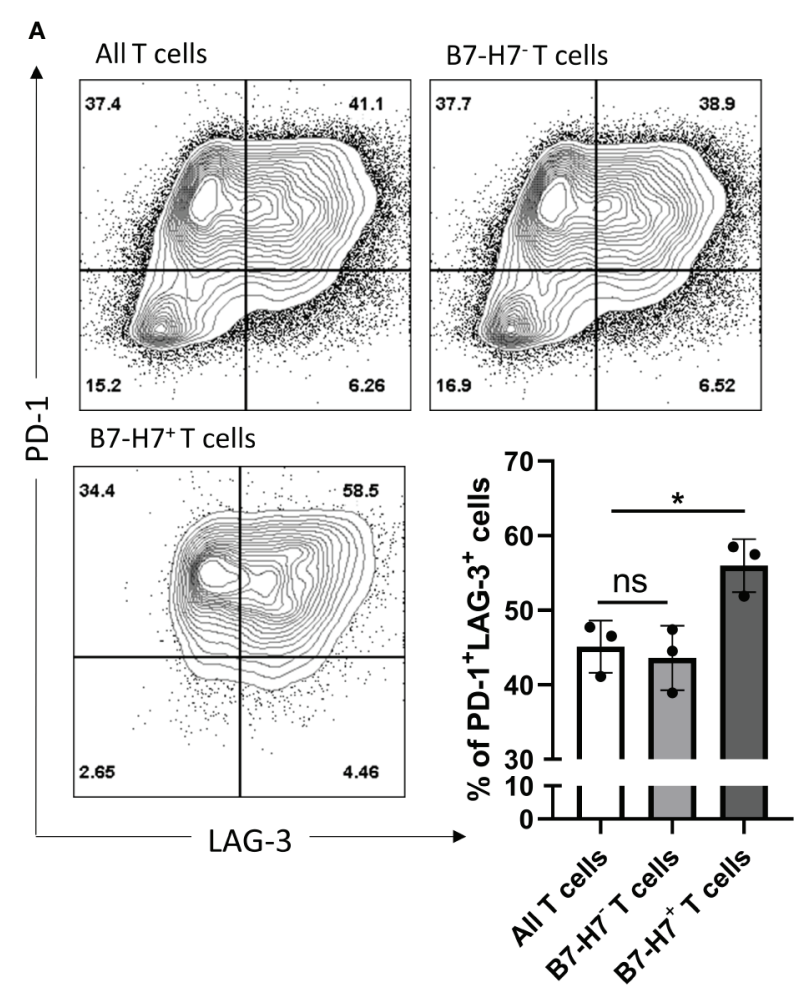

B $\mathrm{CD}^{+} \mathrm{T}$ cells

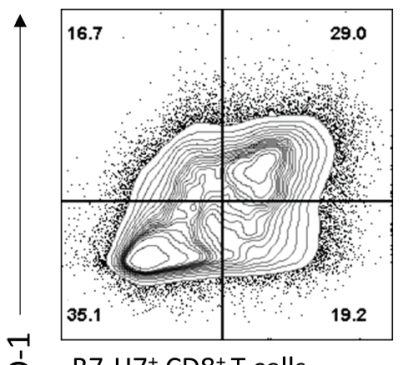

B7-H7- CD8 ${ }^{+} \mathrm{T}$ cells

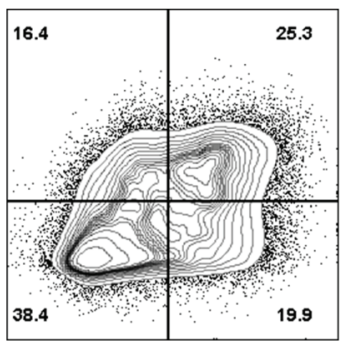

仓่
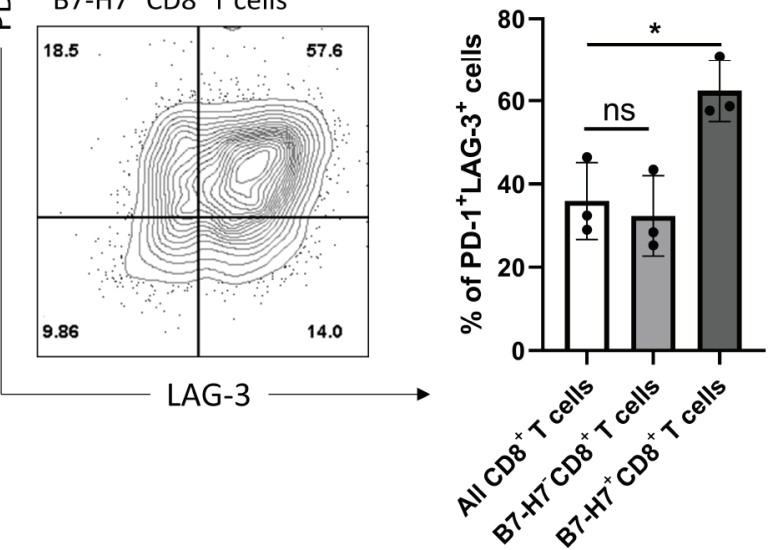

FIGURE 6 | B7-H7 $7^{+}$T cells show an exhausted phenotype. Purified T cells (A) or purified $\mathrm{CD} 8^{+} \mathrm{T}$ cells $\mathbf{( B )}$ were activated with recommended dose of TransAct $^{\mathrm{TM}}$ (1:100) for three days and assessed for B7-H7, PD-1 and LAG-3, $n=3$. Cells were gated for live and single cells. ns, not significant, ${ }^{*} p<0.05$, one-way ANOVA was used, followed by multiple comparison tests. primary $\mathrm{T}$ cells express $\mathrm{B} 7-\mathrm{H} 7$ upon activation which act as a regulatory mechanism to control $\mathrm{T}$ cell activation. The notion that $\mathrm{T}$ cells express both the immune checkpoint molecule and its ligand is not unusual. For instance, $\mathrm{T}$ cells have been reported to express both PD-L1 and PD-L2, in addition to PD-1 (29, 30). B7$\mathrm{H} 7$ is a new member of that group of ligands. The role of B7-H7 in $\mathrm{T}$ cell activation remains controversial. Several studies have shown that ligation of $\mathrm{B} 7-\mathrm{H} 7$ can either stimulate or inhibit $\mathrm{T}$ cell responses $(2,4)$. In analogy to B7.1 and B7.2 that ligate CTLA-4 and $\mathrm{CD} 28$ to inhibit and stimulate $\mathrm{T}$ cell responses respectively, $\mathrm{B} 7-\mathrm{H} 7$ has been shown to ligate KIR3DL3 and $\mathrm{CD} 28 \mathrm{H}$ to inhibit and stimulate $\mathrm{T}$ cell responses respectively (14). However, Rieder et al. showed that the inhibitory effect of $\mathrm{B} 7-\mathrm{H} 7$ signalling is evident as early as $24 \mathrm{~h}$ after the initial stimulation (11). Nevertheless, KIR3DL3 is not expressed on resting T cells and the expression is less than 5\% upon cross-linking CD3 and CD28 (14). It is therefore plausible that other inhibitory receptors that mediate immune regulation by $\mathrm{B} 7-\mathrm{H} 7$ exist.

In this study, we demonstrate that recombinant $\mathrm{CD} 28 \mathrm{H}$ may block $\mathrm{B} 7-\mathrm{H} 7$ and enhance the immune response. However, recombinant $\mathrm{CD} 28 \mathrm{H}$ may not be the most optimal agent to block $\mathrm{B} 7-\mathrm{H} 7$ because it may leave other regions of $\mathrm{B} 7-\mathrm{H} 7$ available for binding to inhibitory receptor(s). A specific antibody that preferentially blocks the interaction between $\mathrm{B} 7$ $\mathrm{H} 7$ and its inhibitory receptor(s), rather than its stimulatory receptor, would likely be more beneficial as an immunotherapy. Currently, there is no commercially available agent that can specifically block the interaction between $\mathrm{B} 7-\mathrm{H} 7$ and immunoinhibitory receptors, while leaving immunostimulatory receptor alone. Rather than blocking B7-H7, which can costimulate $\mathrm{T}$ cells via $\mathrm{CD} 28 \mathrm{H}$, future developments should focus on blocking its inhibitory receptor(s). To get there, the identification of these inhibitory receptor(s) is essential.

Consistent with the findings of Zhao et al., immobilised antiCD3 antibody alone did not induce B7-H7 expression on T cells (2). Furthermore, no induction of B7-H7 was observed upon mitogenic stimulation with PMA and ionomycin. Only when cross-linking CD3 and CD28 or in a mixed lymphocyte reaction, the expression of $\mathrm{B} 7-\mathrm{H} 7$ was significantly increased. It has also been reported before that agonistic anti-CD3 antibody alone or PMA-ionomycin treatment can induce $\mathrm{T}$ cells to produce IL-2 $(31,32)$. Thus, IL-2 alone is not sufficient to induce B7-H7 expression and cannot substitute CD28 signal. However, it cannot be discounted that IL-2 can enhance B7-H7 expression on T cells once B7-H7 is induced. To formally conclude that IL-2 is essential, neutralizing antibodies to IL-2 would have been needed to include in the assays. Thus, further investigation is required to assess the effect of various $\mathrm{T}$ cell-secreted cytokines on B7-H7 expression.

The expression of $\mathrm{B} 7-\mathrm{H} 7$ on $\mathrm{T}$ cells has previously been shown at the mRNA level, since Aznar et al. found that agonistic anti-CD137 antibody enhance B7-H7 mRNA expression, in addition to agonistic anti-CD3 antibody treatment (33). In our hand, the protein expression of $\mathrm{B} 7-\mathrm{H} 7$ did increase in the presence of recombinant human CD137 ligand stimulation in $\mathrm{T}$ cells upon crosslinking CD3 and CD28. These findings demonstrate that the costimulatory signal via CD28/CD137 is essential for $\mathrm{B} 7-\mathrm{H} 7$ to be expressed at protein level on T cells. 
Our data suggests that B7-H7 is preferentially expressed on $\mathrm{CD}^{+} \mathrm{T}$ cells upon activation. Similarly, a recent study in orthotopic KPC tumours showed that the expression of PD-L1 (B7-H1) was expressed in approximately $40 \%$ and $60 \%$ of $\mathrm{CD}^{+}$and $\mathrm{CD} 8^{+} \mathrm{T}$ cells respectively (30). Although there is no clear explanation why $\mathrm{CD}^{+} \mathrm{T}$ cells would express higher levels of immune checkpoint ligands, we speculate that it may provide a faster and stronger negative feedback to inhibit CD8 $\mathrm{T}$ cell cytotoxic responses.

Our results identify B7-H7 as a marker of a subset of Th1 or Tc1 cells that do not secrete TNF- $\alpha$ and IFN- $\gamma$. The fact that $\mathrm{CD} 57$ and $\mathrm{B} 7-\mathrm{H} 7$ are not expressed on the same $\mathrm{T}$ cell suggest that $\mathrm{B} 7-\mathrm{H}^{+} \mathrm{T}$ cells are not senescent or terminally differentiated. Our results show that crosslinking of CD3 and CD28 induces most $\mathrm{T}$ cells to express CXCR3, a marker of type 1 polarization (Th1/Tc1). This is consistent with previous reports showing that CD3 and CD28 activation favours the generation of Th1 and Tc1 T cells $(34,35)$. Furthermore, B7-H7 allows us to better identify $\mathrm{CXCR}^{+}{ }^{+} \mathrm{T}$ cells, as seen by the enrichment of CXCR $3^{+} \mathrm{T}$ cells among the $\mathrm{B} 7-\mathrm{H}^{+} \mathrm{T}$ cells. Thus, it is surprising to find that B7$\mathrm{H}^{+} \mathrm{T}$ cells are poor producers of TNF- $\alpha$ and IFN- $\gamma$.

Upon further investigation, we found that $\mathrm{B} 7-\mathrm{H}^{+} \mathrm{T}$ cells are mostly exhausted, as evidenced by their PD-1 and LAG-3 expression level. We also observed that $\mathrm{B} 7-\mathrm{H}^{+} \mathrm{T}$ cells express a higher level of CTLA-4 and TIM-3 (Figure S5). The overexpression of inhibitory receptors including PD-1 and LAG-3 have been established as markers of T cells exhaustion (36), and that $\mathrm{T}$ cells co-expressing both PD-1 and LAG-3 are significantly more exhausted than $\mathrm{T}$ cells that express either PD-1 or LAG-3 alone (37). Furthermore, PD-1 and LAG-3 has been described to cooperate to maintain functional $\mathrm{T}$ cell exhaustion (38). In this study, we demonstrate that B7-H7 can be used to identify exhausted $\mathrm{T}$ cells since they not only secrete low levels of inflammatory cytokines but also express higher levels of both PD-1 and LAG-3. Since PD-1 can also be expressed on resting T cells, B7-H7 may be better positioned as a late-stage marker of $\mathrm{T}$ cell exhaustion since it is only expressed upon activation (39). Collectively, we have identified that exhausted T cells express B7-H7 and that blockade of B7-H7 improves the proliferation of T cells. While our data does not examine every aspects of $\mathrm{T}$ cell exhaustion, we managed to show decreased secretion of cytokines, as well as co-expression of other immune checkpoints in $\mathrm{B} 7-\mathrm{H}^{+} \mathrm{T}$ cells. This fits in the broad definition of $\mathrm{T}$ cell exhaustion and may introduce B7-H7 into the group of surface markers that define exhausted $\mathrm{T}$ cells.

The distinction between an activation marker and an exhaustion marker is not always clear. The same doubt can be applied for PD-1 and CTLA-4. Both PD-1 and CTLA-4 are rapidly induced on T cells after activation $(40,41)$. As B7-H7 is only induced on activated $\mathrm{T}$ cells, it can also be considered a marker of $\mathrm{T}$ cells activation. However, not every activated T cell expresses B7$\mathrm{H} 7$ and those that do have less cytokine secretion. Hence, we view B7-H7 as an exhaustion marker rather than an activation marker.

As T cells that express B7-H7 limit the activation of bystander $\mathrm{T}$ cells and they themselves do not contribute inflammatory cytokine secretion, a potential application of this finding is that selecting for $\mathrm{B}^{-}-\mathrm{H}^{-} \mathrm{T}$ cells can be considered to improve the efficacy of adoptive $\mathrm{T}$ cell therapy. During a chronic infection, exhausted T cells may express high levels of B7-H7. Whether these $\mathrm{T}$ cells should be targeted remains debatable. Immunoregulation via B7-H7 in particular, and T cell exhaustion in general, may not be inherently good or bad. For instance, $\mathrm{T}$ cell exhaustion is important and evolutionarily conserved to limit autoimmunity, prevent damage to nearby tissues and allow $\mathrm{T}$ cell to survive to contain the infection (15). Further studies are required to explore the impact of targeting B7-H7 during a chronic infection.

Furthermore, it would be interesting to explore the role of B7$\mathrm{H} 7$ expression on intratumoural $\mathrm{T}$ cells to regulate immune responses. Since tumour and chronic infection are the main causes for $\mathrm{T}$ cell exhaustion, it is plausible that intratumoural $\mathrm{T}$ cells have upregulated B7-H7 expression. Further investigation into the different stimuli that induce $\mathrm{B} 7-\mathrm{H} 7$ on T cells may allow us to limit the negative influence of this pathway on immunotherapies. Additionally, it is vital to identify immunoinhibitory receptors for B7-H7. Since the B7-H7 - CD28H interaction may be beneficial for the immune response, it is preferable to block those immunoinhibitory receptors, rather than $\mathrm{B} 7-\mathrm{H} 7$ itself.

In the case of autoimmunity, since many autoimmune conditions are characterised by abnormal $\mathrm{T}$ cell function, it is worth exploring the expression of B7-H7 on T cells. Autoreactive $\mathrm{T}$ cells, being continuously activated, may express B7-H7. For those conditions where $\mathrm{T}$ cells express high $\mathrm{B} 7-\mathrm{H} 7$, it may be logical to block CD28H, while allowing B7-H7 to bind to other immunoinhibitory receptors.

\section{DATA AVAILABILITY STATEMENT}

The original contributions presented in the study are included in the article/Supplementary Material. Further inquiries can be directed to the corresponding author.

\section{AUTHORS CONTRIBUTIONS}

KL performed the experiments, analysed the data and wrote the manuscript. HS and AL supervised the study and wrote the manuscript. All authors contributed to the article and approved the submitted version.

\section{FUNDING}

The study was funded by The Swedish Cancer Society (\#CAN 2018/451) and The Cancer Research Foundations of Radiumhemmet (\#181183).

\section{SUPPLEMENTARY MATERIAL}

The Supplementary Material for this article can be found online at: https://www.frontiersin.org/articles/10.3389/fimmu.2021. 682627/full\#supplementary-material

Supplementary Table 1 | List of staining reagents used for flow cytometry assay. 


\section{REFERENCES}

1. Mager DL, Hunter DG, Schertzer M, Freeman JD. Endogenous Retroviruses Provide the Primary Polyadenylation Signal for Two New Human Genes (HHLA2 and HHLA3). Genomics (1999) 59(3):255-63. doi: 10.1006/ geno.1999.5877

2. Zhao R, Chinai JM, Buhl S, Scandiuzzi L, Ray A, Jeon H, et al. HHLA2 Is a Member of the B7 Family and Inhibits Human CD4 and CD8 T-Cell Function. Proc Natl Acad Sci USA (2013) 110(24):9879-84. doi: 10.1073/ pnas. 1303524110

3. Janakiram M, Chinai JM, Fineberg S, Fiser A, Montagna C, Medavarapu R, et al. Expression, Clinical Significance, and Receptor Identification of the Newest B7 Family Member HHLA2 Protein. Clin Cancer Res (2015) 21 (10):2359-66. doi: 10.1158/1078-0432.CCR-14-1495

4. Zhu Y, Yao S, Iliopoulou BP, Han X, Augustine MM, Xu H, et al. B7-H5 Costimulates Human T Cells Via CD28H. Nat Commun (2013) 4:2043. doi: $10.1038 /$ ncomms3043

5. Jing CY, Fu YP, Yi Y, Zhang MX, Zheng SS, Huang JL, et al. HHLA2 in Intrahepatic Cholangiocarcinoma: An Immune Checkpoint With Prognostic Significance and Wider Expression Compared With PD-L1. J Immunother Cancer (2019) 7(1):77. doi: 10.1186/s40425-019-0554-8

6. Koirala P, Roth ME, Gill J, Chinai JM, Ewart MR, Piperdi S, et al. HHLA2, a Member of the B7 Family, Is Expressed in Human Osteosarcoma and Is Associated With Metastases and Worse Survival. Sci Rep (2016) 6:31154. doi: $10.1038 /$ srep31154

7. Alonso R, Flament H, Lemoine S, Sedlik C, Bottasso E, Peguillet I, et al. Induction of Anergic or Regulatory Tumor-Specific CD4(+) T Cells in the Tumor-Draining Lymph Node. Nat Commun (2018) 9(1):2113. doi: 10.1038/ s41467-018-04524-x

8. Zhu Z, Dong W. Overexpression of HHLA2, a Member of the B7 Family, Is Associated With Worse Survival in Human Colorectal Carcinoma. Onco Targets Ther (2018) 11:1563-70. doi: 10.2147/OTT.S160493

9. Santana MA, Esquivel-Guadarrama F. Cell Biology of T Cell Activation and Differentiation. Int Rev Cytol (2006) 250:217-74. doi: 10.1016/S0074-7696 (06)50006-3

10. Azuma M. Co-Signal Molecules in T-Cell Activation. In: M Azuma, H Yagita, editors. Co-Signal Molecules in T Cell Activation: Immune Regulation in Health and Disease. Singapore: Springer Singapore (2019). p. 3-23.

11. Rieder SA, Wang J, White N, Qadri A, Menard C, Stephens G, et al. B7-H7 (HHLA2) Inhibits T-Cell Activation and Proliferation in the Presence of TCR and CD28 Signaling. Cell Mol Immunol (2020). doi: 10.1038/s41423-0200361-7

12. Wang J-h, Manick B, Wu G, Hao R. Biofunctions of Three New B7 Family Members (IRM7P.486). J Immunol (2014) 192(1 Supplement) 126.11.

13. Zhuang X, Long EO. Cd28 Homolog Is a Strong Activator of Natural Killer Cells for Lysis of B7H7(+) Tumor Cells. Cancer Immunol Res (2019) 7(6):93951. doi: 10.1158/2326-6066.CIR-18-0733

14. Bhatt RS, Berjis A, Konge JC, Mahoney KM, Klee AN, Freeman SS, et al. KIR3DL3 Is an Inhibitory Receptor for HHLA2 That Mediates an Alternative Immunoinhibitory Pathway to PD1. Cancer Immunol Res (2020) 9(2):156169. doi: 10.1158/2326-6066.Cir-20-0315

15. Blank CU, Haining WN, Held W, Hogan PG, Kallies A, Lugli E, et al. Defining 'T Cell Exhaustion'. Nat Rev Immunol (2019) 19(11):665-74. doi: 10.1038/ s41577-019-0221-9

16. Uhlen M, Karlsson MJ, Zhong W, Tebani A, Pou C, Mikes J, et al. A GenomeWide Transcriptomic Analysis of Protein-Coding Genes in Human Blood Cells. Science (2019) 366(6472):eaax9198. doi: 10.1126/science.aax9198

17. Iqbal J, Wright G, Wang C, Rosenwald A, Gascoyne RD, Weisenburger DD, et al. Gene Expression Signatures Delineate Biological and Prognostic Subgroups in Peripheral T-Cell Lymphoma. Blood (2014) 123(19):2915-23. doi: 10.1182/blood-2013-11-536359

18. Bhojwani D, Kang H, Menezes RX, Yang W, Sather H, Moskowitz NP, et al. Gene Expression Signatures Predictive of Early Response and Outcome in High-Risk Childhood Acute Lymphoblastic Leukemia: A Children's Oncology Group Study [Corrected]. J Clin Oncol (2008) 26(27):4376-84. doi: 10.1200/ JCO.2007.14.4519

19. Dubois S, Viailly PJ, Bohers E, Bertrand P, Ruminy P, Marchand V, et al. Biological and Clinical Relevance of Associated Genomic Alterations in
MYD88 L265P and Non-L265P-Mutated Diffuse Large B-Cell Lymphoma: Analysis of 361 Cases. Clin Cancer Res (2017) 23(9):2232-44. doi: 10.1158/ 1078-0432.CCR-16-1922

20. Noordermeer SM, Sanders MA, Gilissen C, Tonnissen E, van der Heijden A, Dohner K, et al. High BRE Expression Predicts Favorable Outcome in Adult Acute Myeloid Leukemia, in Particular Among MLL-AF9-positive Patients. Blood (2011) 118(20):5613-21. doi: 10.1182/blood-2011-06-359182

21. Van Vlierberghe P, van Grotel M, Tchinda J, Lee C, Beverloo HB, van der Spek PJ, et al. The Recurrent SET-NUP214 Fusion as a New HOXA Activation Mechanism in Pediatric T-Cell Acute Lymphoblastic Leukemia. Blood (2008) 111(9):4668-80. doi: 10.1182/blood-2007-09-111872

22. Drexler HG, Gignac SM, Hoffbrand AV, Leber BF, Norton J, Lok MS, et al. Characterization of Hodgkin's Disease Derived Cell Line HDLM-2. Recent Results Cancer Res (1989) 117:75-82. doi: 10.1007/978-3-64283781-4_8

23. Mannick JB, Del Giudice G, Lattanzi M, Valiante NM, Praestgaard J, Huang B, et al. mTOR Inhibition Improves Immune Function in the Elderly. Sci Transl Med (2014) 6(268):268ra179. doi: 10.1126/scitranslmed.3009892

24. Lastwika KJ, Wilson W3rd, Li QK, Norris J, Xu H, Ghazarian SR, et al. Control of PD-L1 Expression by Oncogenic Activation of the AKT-mTOR Pathway in Non-Small Cell Lung Cancer. Cancer Res (2016) 76(2):227-38. doi: 10.1158/ 0008-5472.CAN-14-3362

25. Sun SY. Searching for the Real Function of mTOR Signaling in the Regulation of PD-L1 Expression. Transl Oncol (2020) 13(12):100847. doi: 10.1016/ j.tranon.2020.100847

26. Mousset CM, Hobo W, Woestenenk R, Preijers F, Dolstra H, van der Waart AB. Comprehensive Phenotyping of T Cells Using Flow Cytometry. Cytomet Part A (2019) 95(6):647-54. doi: 10.1002/cyto.a.23724

27. Jones D, O'Hara C, Kraus MD, Perez-Atayde AR, Shahsafaei A, Wu L et al. Expression Pattern of T-Cell-Associated Chemokine Receptors and Their Chemokines Correlates With Specific Subtypes of T-cell nonHodgkin Lymphoma. Blood (2000) 96(2):685-90. doi: 10.1182/ blood.V96.2.685

28. Langenkamp A, Nagata K, Murphy K, Wu L, Lanzavecchia A, Sallusto F. Kinetics and Expression Patterns of Chemokine Receptors in Human CD4+ T Lymphocytes Primed by Myeloid or Plasmacytoid Dendritic Cells. Eur J Immunol (2003) 33(2):474-82. doi: 10.1002/immu.200310023

29. Messal N, Serriari NE, Pastor S, Nunes JA, Olive D. Pd-L2 Is Expressed on Activated Human T Cells and Regulates Their Function. Mol Immunol (2011) 48(15-16):2214-9. doi: 10.1016/j.molimm.2011.06.436

30. Diskin B, Adam S, Cassini MF, Sanchez G, Liria M, Aykut B, et al. Pd-L1 Engagement on $\mathrm{T}$ Cells Promotes Self-Tolerance and Suppression of Neighboring Macrophages and Effector T Cells in Cancer. Nat Immunol (2020) 21(4):442-54. doi: 10.1038/s41590-020-0620-x

31. Welte K, Platzer E, Wang CY, Rinnooy Kan EA, Moore MA, Mertelsmann R. OKT8 Antibody Inhibits OKT3-Induced IL 2 Production and Proliferation in OKT8+ Cells. J Immunol (1983) 131(5):2356-61.

32. Boulougouris G, McLeod JD, Patel YI, Ellwood CN, Walker LSK, Sansom DM. Il-2-Independent Activation and Proliferation in Human T Cells Induced by CD28. J Immunol (1999) 163(4):1809-16.

33. Aznar MA, Labiano S, Diaz-Lagares A, Molina C, Garasa S, Azpilikueta A, et al. Cd137 (4-1bb) Costimulation Modifies DNA Methylation in CD8(+) T Cell-Relevant Genes. Cancer Immunol Res (2018) 6(1):69-78. doi: 10.1158/ 2326-6066.CIR-17-0159

34. Bonyhadi M, Frohlich M, Rasmussen A, Ferrand C, Grosmaire L, Robinet E, et al. In Vitro Engagement of CD3 and CD28 Corrects T Cell Defects in Chronic Lymphocytic Leukemia. J Immunol (2005) 174(4):2366-75. doi: 10.4049/jimmunol.174.4.2366

35. Mazur MA, Davis CC, Szabolcs P. Ex Vivo Expansion and Th1/Tc1 Maturation of Umbilical Cord Blood T Cells by CD3/CD28 Costimulation. Biol Blood Marrow Transplant (2008) 14(10):1190-6. doi: 10.1016/ j.bbmt.2008.07.016

36. Pauken KE, Wherry EJ. Snapshot: T Cell Exhaustion. Cell (2015) 163 (4):1038-.el. doi: 10.1016/j.cell.2015.10.054

37. Du H, Yi Z, Wang L, Li Z, Niu B, Ren G. The Co-Expression Characteristics of LAG3 and PD-1 on the T Cells of Patients With Breast Cancer Reveal a New Therapeutic Strategy. Int Immunopharmacol (2020) 78:106113. doi: 10.1016/ j.intimp.2019.106113 
38. Okagawa T, Konnai S, Deringer JR, Ueti MW, Scoles GA, Murata S, et al. Cooperation of PD-1 and LAG-3 Contributes to T-Cell Exhaustion in Anaplasma Marginale-Infected Cattle. Infect Immun (2016) 84(10):2779-90. doi: 10.1128/IAI.00278-16

39. Sauce D, Almeida JR, Larsen M, Haro L, Autran B, Freeman GJ, et al. PD-1 Expression on Human CD8 T Cells Depends on Both State of Differentiation and Activation Status. AIDS (2007) 21(15):2005-13. doi: 10.1097/ QAD.0b013e3282eee548

40. Chan DV, Gibson HM, Aufiero BM, Wilson AJ, Hafner MS, Mi QS, et al. Differential CTLA-4 Expression in Human CD4+ Versus CD8+ T Cells Is Associated With Increased NFAT1 and Inhibition of CD4+ Proliferation. Genes Immun (2014) 15(1):25-32. doi: 10.1038/gene.2013.57

41. Chikuma S, Terawaki S, Hayashi T, Nabeshima R, Yoshida T, Shibayama S, et al. Pd-1-Mediated Suppression of IL-2 Production Induces CD8+ T Cell
Anergy In Vivo. J Immunol (2009) 182(11):6682-9. doi: 10.4049/ jimmunol.0900080

Conflict of Interest: The authors declare that the research was conducted in the absence of any commercial or financial relationships that could be construed as a potential conflict of interest.

Copyright (c) 2021 Luu, Schwarz and Lundqvist. This is an open-access article distributed under the terms of the Creative Commons Attribution License (CC BY). The use, distribution or reproduction in other forums is permitted, provided the original author(s) and the copyright owner(s) are credited and that the original publication in this journal is cited, in accordance with accepted academic practice. No use, distribution or reproduction is permitted which does not comply with these terms. 